\title{
Zimbabwean Politics from the Ground Up
}

David Moore

University of Johannesburg, South Africa

On Rutherford, Blair. Farm Labor Struggles in Zimbabwe: The Ground of Politics. Bloomington: Indiana University Press, 2017, 294 pages.

Now, around the time of writing in late 2019, might be the time for students of political affairs to take the profound lessons from Blair Rutherford's stunningly superb ethnography seriously. ${ }^{1}$ After ruling for 37 years, before exiting at the end of 2017 on the occasion of a coup petit executed by one faction within his own party (Moore 2018), and at 95 years of age, Zimbabwe's past president finally saw the sense in dying. ${ }^{2}$ The publication of The Ground of Politics ${ }^{3}$ just might allow the many gazes on Zimbabwean politics to shift focus from the élite not only to the subalterns, but to the ways in which the discourse and practice of both groups, and the many intersecting fractions and factions within them, relate to and influence each other. Rutherford offers a subtle grasp of theory

I I say students of political affairs deliberately because political anthropologists probably don't need this advice. Not being one of those, I really can't say. The dominant political science mode either ignores the subaltern classes or crunches them into numbers. Even those who try rarely escape the epistemologies of their class. To be sure, the leftists from the sixties generation who taught in the late 1970s and the 1980s helped, with their forays into historical political economy and a critical development studies mode, but teleological problems remain. In any case, they have a lot to learn from ethnographies of the subaltern.

2 On this borrowed idea of seeing the sense in dying, see Kamel Daoud's The Mersault Investigation (2015, 3I), in which the protagonist wonders if dying "didn't make sense anymore" to his elderly mother.

3 This might have been the first clause of the book's title, if Rutherford's intent had been followed through. The Ground of Politics: Farm Workers' Struggles in Zimbabwe would have registered its important epistemological shift more immediately. 
and keen storytelling: combined with a nuanced take on national and 'domestic' modes of governance, ${ }^{4}$ and his book offers just the needed shift in focus.

Might political analysts grow tired of delving into the myriad manoeuvres of the members of the political class who differ only in their constructions of generation, ethnicity, and cabals; in how they accumulate their corrupt gains; with which security cluster they arm themselves; or whether they mouth platitudes with or against 'the west'? Might political analysts see that whatever new (or just slightly different, in this case) faces rise to the top, daily politics at the summit of power doesn't change much (other than getting worse)? Ought they to venture a few score kilometres outside the cities (or even closer, into the 'low density suburbs') to see politics work on the terrain where most people live? One would think so. Yet maybe not, even if they should be encouraged to do so by reading this book.

Why not? One of the many strengths of the book is that its pointillist illustrations of farm-workers' battles with a nouveau bourgeois noir agricultural company (and later with a variety of much more complex forces) are viewed through a wide-angle lens on the tumultuous shifts in the national body-politic taking place near the turn of the millennium. As the battle on the farm is resolved (more or less), the bigger battle on the wider, national canvas takes the jambjana turn. The fine details on the commercial farms and their immediate context mesh intricately with a near war country-wide.

Jambjana is a Shona term, referring to the 'invasion' of many white farms, and the wider and wider spread of violence, with local party and state officials torn in myriad directions. Thus, at a time when in the crudest sense, it looked like all political things were possible for those who wanted release from the ruling party's two decades of political repression and economic regression, and all it would take is a new political party's electoral victory to do a clean sweep, politics on the ground was much more complex. Twenty years later-mired in devastating economic disaster and diminishing expectations for a political opposition that looked promising in this book's day-it seems that a close look at subaltern politics à la Rutherford would just add more confusion to the stalemated crises afflicting Zimbabwe. Political scientists would be tearing their hair out, as their ideas, stuck in a singular élite's 'predatory politics' (Bratton 2014), are unstuck quickly. Thus, maybe the student of politics will not turn to Blair's book.

4 This formulation borrows on Rutherford's (200I) classic analysis of 'domestic government.' 
One main narrative point of The Ground of Politics is that this jambjana moment was Zimbabwe's most important political turning point since majority rule in 1980. The wave of liberal democracy spreading across Africa in the post-Cold War moment (for example, Moore 2016) allowed a strong and newly independent trade union congress to join up with human rights and constitution-oriented groups to form the Movement for Democratic Change (MDC). Given the ravages of a belated structural adjustment program in Zimbabwe, it seemed as if a form of social democracy might just work. It was evident to most, that this, not Margaret Thatcher's, was the "only alternative".

At one level, it is the national and the local that merge so well in The Ground of Politics. A liberal discourse of human rights blended with its 'second generation' to lend credible weight to the demands of the agricultural workers whom Rutherford grew to know and like both incredibly well, and, in his wise hindsight, reflexively. These agricultural workers' needs and demands resonated with the new national discourse of a political party born of a February 1999 conference mandating a workers' party. And it was workers (in a complex way) that these people were, in spite of their rural (and impoverished) homes. The agricultural workers Rutherford writes about lived far closer to the big capitalist farms than did their city brothers and sisters to their workplaces, in more distanced locations. Aside from the vertical connections of race, nationhood, and homesteads, it was the horizontal connections of class, union, and party which seemed to be gelling.

Indeed, one of Rutherford's urban protagonists is professor, lawyer, and radical socialist activist Munyaradzi Gwisai, who epitomised both the links between country and city and the most elevated mode of Marxist analysis, in the Trotskyist International Socialist Organisation realm, that such struggles entailed. Much of the detailed and somewhat obscure legal negotiations that Rutherford describes, and which occurred as result of the blunter 'war' on and to the side of the farm where it centred, were carried out at Gwisai's Zimbabwe Labour Centre in Harare. The Ground of Politics is replete with the contradictions of such a process. The struggle for compensation after abrupt layoffs is full of tensions, lies, dashed deals, fading hopes, desperate strategies of coping, shifting political allegiances and alliances, opacity, shady local politicians, and terrible national ones. If made into a TV series, The Ground of Politics would be Zimbabwe's subaltern West Wing. However, more than a modicum of 'progress' can be seen in these first couple of years (for example, Moore, Kriger and Raftopoulos 2013). 
But this struggle for compensation after the abrupt layoffs may have marked the beginning and the end of the convergence of the rural and urban, fragile, and contingent as Rutherford makes it out to be. This moment was also when the War Vets' 1997 deal with Mugabe, as he was reaching the end of one of his many tethers, was consummated. The workers and opposition party appeared to be on the verge of displacing ZANU (PF), Mugabe's political home. So, Mugabe made his last, very reluctant, civilian alliance with what Thabo Mbeki soon after called the "lumpen-proletariat." fulfil his many previous (unfulfilled) promises regarding land for the tillers.

More than I,40o large scale commercial farms, most with white owners, were slated for the taking. When the abrogation of property rights was announced in parliament, which occurred concurrent to Zimbabwean's involvement in the war in the Democratic Republic of the Congo, costing over a million US dollars a day, much followed. The value of the Zimbabwean dollar started its precipitous slide, so much so that a decade later the worthless currency had to be abandoned and replaced with the US dollar. The processes leading up to the MDC had begun. Not a few white farmers, as well as their workers, saw in the MDC a possible saviour. The result was a complex alliance which turned Mugabe against both business and labour. (Much later-but not in this book-the MDC would drop a workers' agenda in favour of something indistinguishable from liberalism. A liberalism shared, with some duplicity, by the 2017 coup-masters).

A 1998 UNDP land conference was called, but none of its recommendations went anywhere. A new constitution was discussed all over the country, but when Mugabe removed the 'two terms and you are out' clause at the last moment, the referendum taking it to the people was lost. This loss, seen by Mugabe as the result of white farmers convincing their workers to vote 'no,' in combination with an upcoming election looking like it would be lost to the new party on the block, led almost inevitably to the land invasions. The land had been promised in 1997 to the War Vets, but it had been given very slowly. The land invasions were the last straw on Zimbabwe's economic back, because a lot of Zimbabwe's industry relied on its commercial agriculture. Thus, with the invasions, the two

5 Thabo Mbeki (200I), 'How Will Zimbabwe Defeat Its Enemies? A Discussion Document,' African National Congress mimeograph, Io July 20oI, republished with some changes in 'The Mbeki-Mugabe Papers: A Discussion Document, (not for publication or distribution) August 200I', New Agenda, 2nd Quarter (2008). This paper, which reads like a Stalinized version of a World Bank/IMF guide to good governance, is vociferously critical of the land invasions, and is discussed in Moore (2010). 
cornerstones of Zimbabwe's health and material wealth disappeared. The West's back was up, too, which resulted in various forms of sanctions. The IMF and World Bank found their dealings annulled, and there emerged an uncanny degree of support for the MDC.

With all of this, so too went the trade unions, and thus the formalised link between town and country was sundered. With over $90 \%$ of Zimbabweans without wages, all the urban and rural connections became informal (Sachikonye, Raftopoulos, and Kanyenze 20I8). Just as a working-class-based political party began to emerge, it started to disappear as Zimbabwe deindustrialized. As Rutherford shows, almost sadly, by the time of a 2002 visit, the protagonists of the original labour battle had become more and more intertwined with "authority within electoral politics" or poritikisi. Their status as part of the 'motive force' of history, even though it was on the lowest of rungs, grew more fragile than ever.

This entanglement increasingly made many of them "former farm workers" with even more precarious livelihoods, as the mode of belonging of domestic government was directly attacked and undermined. Farm workers and former farm workers had to attach themselves to territorialized forms of power that were even more conditional as they operated through the extremely precarious landscapes of jambanja. Electoral politics began to reshape the grounds of everyday life throughout Zimbabwe, but nowhere as dramatically and effectively as the lands and social landscapes of commercial farms.... [requiring] new forms of dependency as well as a whole new set of vulnerabilities and fears [including misreading and inflated rumours of researchers' involvement] $(192,198){ }^{6}$

By 2019, the factional politics within ZANU (PF), having resulted in the mini-coup and with the apparent ability of Mugabe to pull their strings even beyond the grave (Hungwe 2019), now have as much or more effect than 'electoral politics' during the early 2000s. No wonder the political analysts have stayed clear. They would have no idea what 'mode of belonging' they belonged to, identified with, or should study.

The phrase 'modes of belonging' is mentioned at least eighteen times in the book, with some intense discussion. What does Rutherford mean with it anyway? It goes a lot further than the old 'mode of production' motif but seems rooted

6 Compare with Hartnack (2016). 
in the 'articulation of modes of production' debates in the sixties and seventies, as brought into the southern African milieu by Harold Wolpe (Friedman 20I5; Moore 2019).

Rutherford uses the term to describe the "routinized discourses, social practices, and institutionalised arrangements through which people make claims for resources and rights ... energize and are entangled with 'social projects,' which are organized aims and efforts of action" (I6, I9). When in turn these projects become "routinized forms of control over specific localities, they can become modes of belonging themselves" (I8). As new social projects are developed, they "are invigorated by, cross through, or even oppose such modes of belonging at various, potentially overlapping, scales of action" (I8). These are, of course, "entangled in assertions of leadership, aims to bolster, affirm or create public authority" (I8) often over territory of various shapes and sizes (the traditional locus of sovereignty) but are also unstable and tentative projects predicated on a will to rule and violence. All of these modes are sedimented with layers evolved over time. When the biggest locus of sovereignty (the state) comes into question and new institutions (that is, political parties) struggle over it, the jambjana of poritikisi permeates throughout. Rutherford suggests that this is a better way to understand how "the transformation of property and labour relations" (249-250) has proceeded "in the name of politics on the national scale" (246) than the prevailing narrow, but hegemonic, interpretations of struggles over rights and redistribution and definitions of social categories.

These ideas of changes in property and labour relations are reminiscent of-but broader than - the mid-2 ${ }^{\text {th }}$ century ideas of transformations of and links among modes of production, but this remains between Rutherford's lines. Perhaps this is due to a Foucauldian take, which could have been augmented by a closer examination of what happens "in the name of politics on the national scale" (250). Furthermore, a clearer focus on how these social relations articulate with accumulation strategies, imbricated to be sure in modes of belonging but perhaps dominant within them, might have cast more light on the complexities of this belonging. Foucault did emerge in the 'articulation' milieu of Althusser and others, but proceeded to move more to 'governmentality', rather than the more pedestrian concerns of wealth creation and primitive accumulation. Rutherford himself spends time examining the moves of the former workers from their wages to trade, and their shifts from 'communal' modes to rent or barter (for example, Chimhowu and Woodhouse 2006, 2010), including selling sex, as they slipped further and further into the un-belonging modes of penury. 
Such excursions could be tied closer to the ways in which shifts in party allegiance and conflict mediation interact with accumulation and survival. It would probably not be possible to create a taxonomy of twelve "modes of social relations of production and reproduction", as did Robert Cox $(1987)^{7}$ when he was moving from the global to the local over long spans of time, but such efforts might be tighter than 'social projects' and 'belonging.' Maybe too tight, though, and verging on the teleological. Still, one wonders if Zimbabwe is trapped within a Gordian knot of entwined modes of belonging (and alienation, or ... perish the thought, transition) and what knives it will take to untie them. The only surety here lies in the fact that The Ground of Politics is the best 'guide' to the knot that exists. It is unlikely that those who study 'the State of Politics' will be able to untie or sever the knot, without a clear understanding of Rutherford's ploughing through the terrain: it's fertile, but hard.

\section{David Moore,}

University of Johannesburg, South Africa,

David.Moore@wits.ac.za

\section{References}

Anderson, Perry. 20I7. The Antinomies of Antonio Gramsci. London: Verso.

Bratton, Michael. 20I4. Power Politics in Zimbabwe. Boulder: Lynne Rienner.

Chimhowu, Admos, and Phil Woodhouse. 2006. "Customary vs. Private Property Rights? Dynamics and Trajectories of Vernacular Land Markets in Sub-Saharan Africa." Journal of Agrarian Change 6(3): 364-37I. https://doi.org/IO.IIII/j.I47I-0366.2006. ool25.x

Chimhowu, Admos, and Woodhouse, Phil. 20I0. "Forbidden but Not Suppressed: A 'Vernacular' Land Market in Svosve Communal Lands." Africa 8o(I): I4-35. https:// doi.org/I0.3366/Eooo197200900I247

Cox, Robert. 1987. Production, Power, and World Order: Social Forces and the Making of History. New York: Columbia University Press.

Daoud, Kamel. 2015. The Mersault Investigation. London: Oneworld.

7 Cited in Anderson (2017, I46). 
Friedman, Steven. 20I5. Race, Class and Power: Harold Wolpe and the Radical Critique of Apartheid. Scottsville: University of KwaZulu-Natal Press.

Hartnack, Andrew. 20I6. Ordered Estates: Welfare, Power and Maternalism on Zimbabwe's (Once White) Highveld. Scottsville SA: University of Kwazulu-Natal Press.

Hungwe, Brian. 2019. "Letter from Africa: The dilemma of how to appease Mugabe's spirit." BBC News, 28 September 20I9. https://www.bbc.com/news/world-africa49824596 (accessed I4 April 202I).

Moore, David. 2019. "Review Article: Articulations, More Articulations ... and Accumulation." Transformation 99 (June): 8I-II2. DOI: IO.I353/trn.20I9.00I2

Moore, David. 20I8. "A Very Zimbabwean Coup: November I3-24 20I7 - Context, Event, Prospects." Transformation 97 (August): I-29. DOI:IO.I3I4O/RG.2.2.I9729.3824I

Moore, David. 2015. "An Arc of Authoritarianism over Africa: Toward the End of a Liberal Democratic Dream?" In Socialist Register 20I6: The Politics of the Right, edited by Leo Panitch and Greg Albo, Vol 52, I93-2I2. London: Merlin Press, 2015.

Moore, David. 20Io. "A Decade of Disquieting Diplomacy: South Africa, Zimbabwe and the Ideology of the National Democratic Revolution, 1999-2009." History Compass 8(8):752-767. https://doi.org/IO.IIII/j.I478-0542.20I0.007I3.X

Moore, David, Norma Kriger and Brian Raftopoulos (eds). 2013. Progress' in Zimbabwe: The Past and Present of a Concept and a Country. London: Routledge.

Sachikonye, Lloyd, Raftopoulos, Brian, and Godfrey Kanyenze (eds). 20I8. Building from the Rubble the Labour Movement in Zimbabwe since 20oo. Harare: Weaver Press.

Rutherford, Blair. 200I. Working on the Margins: Black Workers, White Farmers in PostColonial Zimbabwe. London: Zed Books. 